\title{
A novel application of phosphogypsum: Treatment of a diamond mine's slimes tailings
}

\author{
JH Potgieter ${ }^{1 *}$ and C Green ${ }^{2}$ \\ ${ }^{1}$ School of Chemical and Metallurgical Engineering, University of the Witwatersrand, Private Bag X3, Wits 2050, South Africa \\ ${ }^{2}$ Department of Chemical and Metallurgical Engineering, Tshwane University of Technology, Private Bag X680, Pretoria 0001, \\ South Africa
}

\begin{abstract}
Premier Mine's current slimes dam is nearing the end of its operational life. This is aggravated by a large volume of poor quality water in the dam which is not being recycled back into the process. The poor quality water is the result of a stable colloidal suspension formed from the dominant clay species present in the kimberlitic ore body.

The main objective of this test work was to clarify the water to improve the quality for reuse. Phosphogypsum has been identified as an alternative coagulant to clarify the slimes dam water at a relatively low cost. Laboratory- and plant-scale test work was done to investigate the optimum gypsum dosage, as well as to determine the most suitable application technique. The test work showed that gypsum can successfully destabilise the colloidal suspension. However, poor settling rates were achieved. This improved when the gypsum was added in a slurry form in two stages. The addition of flocculants to aid in settling did not have the desired effect, with resultant high consumption and operating costs.

Toxicity tests indicated no lethality to Daphnia organisms and showed a positive growth in the algae test. The establishment of a monitoring programme will assist in determining the long-term effects of gypsum on the environment.
\end{abstract}

Keywords: water treatment, slimes dam, colloidal effluent, phosphogypsum

\section{Introduction}

The use of coagulants and flocculants to enhance settling of colloidal clay suspensions is a well-known practice in water treatment. Clay characteristics and clay-water interactions are complex natural systems in which variables such as clay mineralogy and water quality determine the colloidal characteristics of the slurry system. Kimberlitic ore has some unique mineralogical characteristics, due to the abundance of the smectite clay group, talc, mica and chlorites. For the kimberlite to coagulate, it is necessary to reduce the net charge on the suspended particles by the adsorption of metal cations. Good quality water in contact with kimberlitic ore results in ion-exchange between the water and the ore, due to the characteristic of the smectite clay group that isomorphous substitution can take place in the tetrahedral and octahedral layers in its crystal structure.

This can result in a change in the concentration of the dissolved ionic species in solution and the $\mathrm{pH}$ of the solution. Increases in the silica, carbonate and sulphate levels lead to a reduction in the free divalent ion concentrations due to the formation of ion pairs, while at the same time increasing the sodium ion concentration dramatically. According to Vietti (1991), this can alter the sodium adsorption ratio (SAR) of the water to favour the formation of a stable, colloidal slurry in the presence of sodium-exchanged clays.

The Premier diamond mine at Cullinan extracts kimberlitic ore to recover diamonds. The end result of the metallurgical process is course tailings $(\geq+1 \mathrm{~mm})$ and fine tailings or slimes $(>-1 \mathrm{~mm})$. Currently the slimes and tailings are disposed of to

* To whom all correspondence should be addressed.

绝 +2711 717 7546; fax: +2711403 1471;

e-mail: Johannes.potgieter@wits.ac.za or hermanp@,prme.wits.ac.za

Received 14 April 2005; accepted in revised form 21 July 2006. a slimes dam comprising an approximately $80 \mathrm{~m}$ high embankment with a length of about $1100 \mathrm{~m}$ and a capacity of approximately $58 \times 10^{6} \mathrm{~m}^{3}$, (Cutting et al., 1996). Pipes with a diameter of 30 to $40 \mathrm{~mm}$ are used to pump slimes to the dam, where the coarse tailings settle rapidly and finer material remains in suspension. Further separation takes place until only the super-fine material $(<10 \mu \mathrm{m})$ remains permanently suspended in the water. The permanent super-fine suspension in the tailings dam results in a poor quality return water for re-utilisation in the process plant. The colloidal suspension also makes the water unsuitable for application in the diamond recovering section or for use as cooling water. This results in a large demand for raw and potable water, with associated cost implications. Table 1 shows a comparison of the quality of the raw water and process water.

\begin{tabular}{|l|c|c|}
\hline \multicolumn{3}{|c|}{$\begin{array}{c}\text { TABLE 1 } \\
\text { Comparison between raw water and } \\
\text { process water }\end{array}$} \\
\hline Analysis & $\begin{array}{c}\text { Raw water } \\
\text { (river water) }\end{array}$ & $\begin{array}{c}\text { Process water } \\
\text { (slimes dam water) }\end{array}$ \\
\hline $\mathrm{pH}$ & 7.8 & 10 \\
\hline $\mathrm{TDS}(\mathrm{mg} / \ell)$ & 143 & 765 \\
\hline $\mathrm{Alkalinity}\left(\right.$ as $\left.\mathrm{CaCO}_{3}\right)$ & 79 & 234 \\
\hline $\mathrm{Ca}^{2+}(\mathrm{mg} / \mathfrak{l})$ & 13 & 4 \\
\hline $\mathrm{Mg}^{2+}(\mathrm{mg} / \ell)$ & 10 & 1 \\
\hline $\mathrm{Na}^{+}(\mathrm{mg} / \ell)$ & 11 & 240 \\
\hline $\mathrm{K}^{+}(\mathrm{mg} / \ell)$ & 3 & 28 \\
\hline $\mathrm{Cl}^{-}(\mathrm{mg} / \ell)$ & 7 & 25 \\
\hline $\mathrm{SO}_{4}^{2-}(\mathrm{mg} / \ell)$ & 16 & 284 \\
\hline $\left.\mathrm{Hardness}^{2}\right)$ & 70 & 18 \\
\hline $\mathrm{SAR}^{2}(\mathrm{meq} / \ell)$ & 0.6 & 25.5 \\
\hline Turbidity & $<5$ & 2000 \\
\hline
\end{tabular}


The problem of the super-fine clay suspension which deteriorates the water quality and the subsequent large volumes that have to be stored, is further compounded by the fact that there is limited capacity available in the slimes dam. Previous estimations (Green, 2000) have indicated that the remaining operational life of the slimes dam is limited to only 4 to 7 years at the current rate of production activities at the mine.

Most of the commercial settling reagents (for coagulation and flocculation) used in South African industries are imported and can add considerably to the operational costs of mines when large volumes of water (as is typically the case in mine operations) have to be treated. The problematic mineralogy of this specific Kimberlitic ore often makes it difficult to match the correct chemical reagents and dosages to achieve effective flocculation of the solids in the slimes dam. Efforts with mechanical equipment have also enjoyed limited success to date.

The current investigation was launched with two main objectives in mind: firstly, to use more of the slimes dam's water to reduce the cost of water from external sources, and secondly, to lower the level of the dam's contents in order to increase its operational lifespan. Phosphogypsum was investigated as an alternative low-cost settling agent to achieve these aims. Phosphogypsum has a number of well documented uses in the building and construction industry (Cotea et al., 1986; Erdogen et al., 1994; Murakami, 1986; Olmez and Erdem, 1989; Singh et al., 1993; Tabikh and Miller, 1976; Olmez and Yilmaz, 1988; Singh et al., 1984; Potgieter and Howell-Potgieter, 2001; Potgieter et al., 2004), but no recorded use of its application to treat slimes effluents could be found in the literature. The current investigation describes the results obtained when different application modes, various dosages of phosphogypsum and phosphogypsum combined with conventional settling aids were used. An environmental assessment of the treated water was also performed.

\section{Experimental procedure}

\section{Laboratory test work}

Initially, ten screening tests were done to evaluate whether gypsum showed any potential to be used as an alternative coagulant. Most of the screening tests were done using gypsum in a powder form, as it was collected from a waste dump. Slimes samples were treated by either dusting the surface with some gypsum powder or by stirring gypsum slurry into the samples. For the screening tests, a volume of $1 \ell$ of water was used and various masses of phosphogypsum ranging from $0.25 \mathrm{~g}$ to $2 \mathrm{~g}$ were dosed to it in measuring cylinders. Vigorous stirring was done manually for $10 \mathrm{~min}$ to promote contact between the particles and the gypsum. The samples were then left to settle out under gravity. After settling, turbidity measurements were performed to make an initial assessment of the effectiveness of the approach followed.

Following the screening tests, it was decided to do more in-depth investigations. Two types of dosing techniques were investigated, namely dry dosing (dusting the water surface with gypsum powder) and slurry dosing (dispersing the gypsum in water before dosing the water).

\section{Dry dosing}

The surface dusting technique was investigated specifically with the objective of applying this technique to the slimes dam for water clarification purposes (Langefeld, 2001a). This technique would also have the added benefit that no mixing or agitation would be necessary.

A sample of the slimes dam water was taken and placed into a container which was divided into 5 compartments, each compartment having about $2 \ell$ of sample. This would also allow the tests to be done simultaneously and under the same conditions. Each compartment was dusted with a different dosage of dry gypsum powder, except for the control compartment, which was not dusted at all. No agitation was allowed for mixing. The settling rate was measured by the mud bed height as a function of time. The supernatant fluid clarity was measured by a Hach 2000 bench-top turbidity meter at fixed intervals.

\section{Slurry dosing}

The slurry dosing technique was investigated for the purposes of dosing the gypsum into the thickener circuit, thereby clarifying the water internally before the underflow material is pumped out to the slimes dam (Langefeld, 2001b). The gypsum powder was dispersed in the minimum amount of water to ensure that it had little effect on the dosing rates, which were calculated based on the dry mass of gypsum. The added benefit of dispersion was that any lumps present would be broken up, increasing the particle surface area for improved contact. A comparison was done on the reaction times of dry dosing and slurry dosing.

It was also decided to experiment with multiple dosing stages and to evaluate what effect that would have on the settling rates and supernatant clarities. The multiple dosing stages were dosed with different dosage concentrations each time.

\section{Compatibility with flocculants}

The objective was to determine the best-suited flocculants, the optimum dosing rate and the most appropriate dosing method. From the previous laboratory studies done, it was determined that applying two dosing stages is more effective than applying the reagents in a single stage. Therefore, the experimental test work concentrated on establishing the most effective two-stage dosing method.

\section{Determination of the required gypsum dosage}

A series of $1000 \mathrm{ml}$ thickener feed samples was dosed with increasing amounts of gypsum. Five cylinders were used and dosed at $0.5 \mathrm{~g} / \ell, 0.75 \mathrm{~g} / \ell, 1.0 \mathrm{~g} / \ell, 1.25 \mathrm{~g} / \ell$ and $1.5 \mathrm{~g} / \ell$ of gypsum respectively. The samples were stirred vigorously for 10 min and allowed to stand overnight. A visual observation was then made to determine in which samples complete flocculation took place. The lowest concentration of gypsum that resulted in complete destabilisation was determined as the optimum dosage required.

\section{Determination of the most suitable flocculant}

The thickener feed sample was divided into 5 more samples of $1000 \mathrm{ml}$ each. These samples were dosed with a range of flocculants and normal settling tests were done to determine the most effective flocculant (Vietti et al., 1999). The best flocculant was selected based on the clarity of the supernatant fluid produced and the most efficient flocculant consumption.

\section{Determination of the most appropriate dosing method}

As previously mentioned, employing a two-stage dosing technique is more effective than a single stage dosage. Therefore, 
the experimental test work concentrated on determining in what ratio the overall gypsum and flocculant dosage could be split between the first and second dosing stages. Three tests were conducted in which the overall dosage was split in a ratio of 25:75, 50:50 and 75:25 respectively, between the first and second dosage.

A $1000 \mathrm{~m} \ell$ sample of thickener feed was placed in a beaker. The first dosage of gypsum, at $25 \%$ of the overall dosage, was added and the sample was stirred vigorously for $10 \mathrm{~min}$. While the sample was stirred, flocculant was added drop-wise until the first signs of flocculation were observed. The sample was allowed to settle out for a period of time after which the turbid supernatant was decanted into another beaker.

The remaining gypsum, in this case the other $75 \%$, was added and the sample was stirred for a further $10 \mathrm{~min}$. Flocculant was again added drop-wise until flocculation took place to leave a clear supernatant. The contents of the beaker were transferred into a measuring cylinder and a settling test performed. The settling rates were measured in each test and recorded. The above procedure was repeated for the other gypsum ratios.

\section{Plant-scale test work}

Following the laboratory test work, it was decided to investigate a larger body of water subjected to all the environmental factors. The objectives of this test work were to apply a gypsum slurry to the surface of the water to test particle interaction and settling times, and to dose gypsum slurry into the feed pipe, thereby facilitating effective mixing prior to the water reaching the thickener. It was expected to achieve faster settling rates using this method. A production thickener, measuring $30 \mathrm{~m}$ in diameter and having a total volume of $1970 \mathrm{~m}^{3}$, was isolated and prepared for the test work. The thickener was filled with slimes dam water and the volume calculated. A gypsum slurry of about $20 \mathrm{~m}^{3}$ was made-up in a mobile dosing unit to a strength of $0.3 \mathrm{~g} / \ell$. The slurry was agitated by air and circulated by means of a mono pump to prevent the gypsum particles from settling. A hydration period of $1 \mathrm{~h}$ was allowed before dosing took place. The gypsum slurry was then sprayed onto the surface of the water and left to settle out. Daily samples were taken to determine the depth of the slimes bed and the water clarity.

After a week, the procedure was repeated, i.e. a gypsum slurry of $20 \mathrm{~m}^{3}$ was made up in the mobile dosing unit to a strength of $0.3 \mathrm{~g} / \ell$, hydrated for $1 \mathrm{~h}$ and then dosed onto the surface of the water. Again daily samples were taken to determine the depth of the slimes bed and the water clarity. The overall dosage was $0.6 \mathrm{~g} / \ell$. Unfortunately, due to production demands, the second test, where the gypsum slurry was to be injected into the feed pipe, could not be performed.

\section{Environmental test work}

The chemical composition of the phosphogypsum is given in Table 2. Due to the acidic nature of some of the phosphate species (e.g. $\mathrm{Ca}\left(\mathrm{H}_{2} \mathrm{PO}_{4}\right)_{2}$ and $\mathrm{CaHPO}_{4}$ or the so-called acid soluble co-crystallised phosphates) and the presence of the impurities in the gypsum (give a chemical analysis with both the macro- and micro-components making up the gypsum), an Ecological and Hygiene Impact Assessment (EHIA) was done to establish whether gypsum would have any significant impact on the downstream ecology of the region. The main focus was to perform a toxicological analysis on un-clarified slimes dam return water and slimes dam return water clarified

\begin{tabular}{|l|c|}
\hline \multicolumn{2}{|c|}{$\begin{array}{c}\text { TABLE 2 } \\
\text { Chemical composition of the } \\
\text { phosphogypsum used in the } \\
\text { investigation }\end{array}$} \\
\hline $\begin{array}{l}\text { Element } \\
\text { (oxide) }\end{array}$ & $\begin{array}{c}\text { Percentage } \\
\text { composition (m/m) }\end{array}$ \\
\cline { 2 - 2 } & Phosphogypsum \\
\hline $\mathrm{SiO}_{2}$ & 0.2 \\
\hline $\mathrm{Al}_{2} \mathrm{O}_{3}$ & $<0.1$ \\
\hline $\mathrm{Fe}_{2} \mathrm{O}_{3}$ & 0.1 \\
\hline $\mathrm{Mn}_{2} \mathrm{O}_{3}$ & $<0.1$ \\
\hline $\mathrm{TiO}_{2}$ & $<0.1$ \\
\hline $\mathrm{CaO}_{2}$ & 32.4 \\
\hline $\mathrm{MgO}_{2} \mathrm{r}$ & $<0.1$ \\
\hline $\mathrm{P}_{2} \mathrm{O}_{5}$ & 0.71 \\
\hline $\mathrm{SO}_{3}$ & 44.5 \\
\hline $\mathrm{K}_{2} \mathrm{O}$ & $<0.1$ \\
\hline $\mathrm{Na}_{2} \mathrm{O}$ & $<0.1$ \\
\hline $\mathrm{LOI}$ & 21.2 \\
\hline $\mathrm{Total}^{-}$ & 99.4 \\
\hline $\mathrm{F}^{-}$ & 0.51 \\
\hline
\end{tabular}

with gypsum. The untreated slimes dam return water had a milky-grey colour to it, whilst the treated slimes dam water was clear.

The water samples were evaluated by means of a Daphnia pulex lethality test and an algal growth inhibition test, using Selenastrum capricornutum Printz. The tests were carried out according to the procedures described in the Guidelines for Toxicity Bio-assaying of Waters and Effluents in South Africa (Slabbert et al., 1998). The Daphnia test was based on US EPA $(1985 ; 1991)$ methodologies, while the algae test was a modification and miniaturisation of the standard US EPA flask test (US EPA, 1978). Serial dilutions were tested to establish toxicity endpoints, while the dam water was tested directly as a screening test. Daphnia organisms of $24 \mathrm{~h}$ or less in age were used in the toxicity testing. To obtain the necessary number of young organisms for a test, adult females bearing embryos in their brood pouches were removed from a stock culture $24 \mathrm{~h}$ prior to the initiation of a test. They were placed in beakers containing moderately hard water and a food suspension (trout chow, alfalfa and yeast). The test organisms were then transferred to a small intermediary holding beaker and from there to the test beakers. The test conditions when using Daphnia organisms are given in Table 3.

The algae tests were carried out in sterile 24-well tissue culture plates. The test samples of $1.8 \mathrm{ml}$ each were dispensed in four replicate wells with a well volume of $3.5 \mathrm{ml}$. Eight control wells were included per plate. Algae cultures between 4 and $6 \mathrm{~d}$ old were used for toxicity test. The algae inocula were prepared by removing the supernatant medium by means of a sterile Pasteur pipette and a vacuum pump. The cells were suspended in fresh culture medium and the cell concentration determined by means of a haemocytometer. The test and control samples were then inoculated with a final concentration of 200000 cells $/ \mathrm{ml}$. The algae suspension was added at a ratio of 1:1 to a 20-times concentrate of the culture medium and used as $200 \mu \ell$ volumes for inoculation of the test and control samples. The top well of each row of wells received the medium only, i.e. $200 \mu \ell$ of a 1:1 dilution of fresh medium and the 20-times concentrated medium. These solutions served as blanks during the optical density (OD) determinations. 


\begin{tabular}{|c|c|}
\hline \multicolumn{2}{|c|}{$\begin{array}{c}\text { TABLE } 3 \\
\text { Daphnia test conditions }\end{array}$} \\
\hline Parameter & Value \\
\hline Temperature & $20 \pm 2^{\circ} \mathrm{C}$ \\
\hline Light quality & Laboratory illumination \\
\hline Photoperiod & Approximately $12 \mathrm{~h}$ daylight \\
\hline Feeding regime & No feeding \\
\hline Oxygen concentration & As obtained \\
\hline $\mathrm{pH}$ & As obtained \\
\hline Size of test beaker & $50 \mathrm{ml}$ \\
\hline Volume of test sample & $25 \mathrm{ml}$ \\
\hline $\begin{array}{l}\text { Number of organisms per } \\
\text { beaker }\end{array}$ & 5 \\
\hline Number of replicate beakers & 4 \\
\hline $\begin{array}{l}\text { Total number of organisms } \\
\text { per test }\end{array}$ & 20 \\
\hline Test duration & $48 \mathrm{~h}$ \\
\hline Effect measured & $\begin{array}{l}\text { Lethality - no movement of } \\
\text { body or appendages on gentle } \\
\text { prodding }\end{array}$ \\
\hline Interpretation of results & $\begin{array}{l}\text { Lethality } \geq 10 \% \text { is an indication } \\
\text { of toxicity, provided that the } \\
\text { control lethality }<10 \% \text {. }\end{array}$ \\
\hline
\end{tabular}

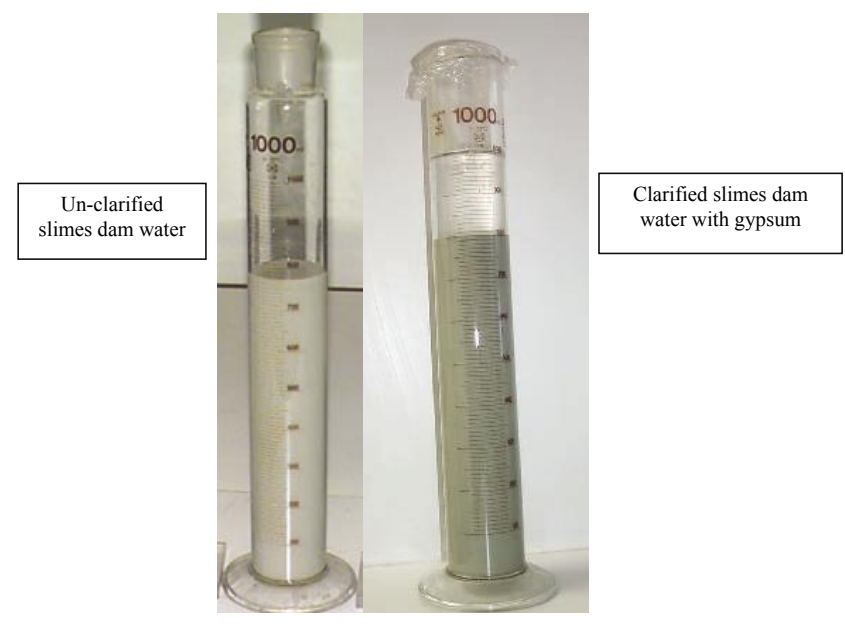

Figure 1

Examples of preliminary screening tests with dry gypsum stirred into the slurry and left to settle compared to a slurry not treated

After inoculation, the OD (optical density) at time zero was determined with a micro-plate reader at $450 \mathrm{~nm}$. Plates were covered with lids and black insulation tape was applied to the perimeters of the closed plates to avoid a higher growth in the outer wells. Incubation was done at $24 \pm 2{ }^{\circ} \mathrm{C}$ for $72 \mathrm{~h}$, using continuous illumination. At the end of the incubation period cells were suspended by means of a micro plate shaker and the growth was measured in terms of OD. The results are expressed as a percentage inhibition (stimulation), calculated as follows:

where:

$$
100 \%-\frac{\left[\left(O D_{T}-O D_{O}\right) \times 100 \%\right]}{O D_{C}-O D_{O}}
$$

$$
\begin{aligned}
& O D_{C}=\text { Average } O D \text { of control } \\
& O D_{T}=\text { Average } O D \text { of test } \\
& O D_{O}=O D \text { at time }
\end{aligned}
$$

A growth inhibition $\leq 20 \%$ was taken as an indication of toxic activity, while a growth stimulation $\geq 20 \%$ was considered as an indication of the presence of nutrients.

\section{Radio-activity measurements}

Phosphogypsum is produced in the phosphoric acid process from raw materials originating from igneous phosphate rock; therefore it contains low levels of radioactive nucleotides. Because the possibility exists that the radiation levels may exceed the minimum standards set by the Nuclear Energy Act (Government Gazette, 1994), it is necessary to determine the levels thereof in the gypsum to obtain a permit from the NNR (National Nuclear Regulator) for the unrestricted use of gypsum. The radioactivity of the gypsum was measured on-site by using a gamma-radiation spectrometer, while thick source alpha counting was employed on sub-samples in the laboratory.

\section{Results and discussion}

\section{Laboratory test work}

The results of the preliminary screening tests are shown in Fig. 1 and indicate that gypsum successfully destabilises the slimes dam return water. Although the settling times achieved with gypsum were very slow compared to those of commercial coagulants, a clear supernatant fluid was obtained. It is known that gypsum has a very low solubility. It is therefore proposed that the limited amount of the gypsum that does go into solution is responsible for the destabilisation of the colloidal solution by means of charge neutralisation of the negative surface charges on the clay particles. However, it is also suspected that the gypsum acts partly as a "flocculant-aid" due to the physical characteristics of the gypsum. On closer inspection, it was found that the gypsum appeared to have a fibrous, needle-like crystal structure. The un-dissolved gypsum crystals therefore facilitate the "capturing" of the destabilised clay particles and promote the settling thereof.

The preliminary tests established that gypsum have the potential to be used as an alternative coagulant to the commercial coagulants on the market. A more in-depth study was consequently done.

\section{Dry dosing}

The surface area of each compartment was measured and found to be about $0.025 \mathrm{~m}^{2}$. The gypsum dosage concentrations added to the 4 test compartments were $80 \mathrm{~g} / \mathrm{m}^{2}, 40 \mathrm{~g} / \mathrm{m}^{2}, 20 \mathrm{~g} / \mathrm{m}^{2}$ and $10 \mathrm{~g} / \mathrm{m}^{2}$ respectively to yield dosages equivalent to $2 \mathrm{~g} / \ell$, $1 \mathrm{~g} / \ell, 0.5 \mathrm{~g} / \ell$ and $0.25 \mathrm{~g} / \ell$ respectively. The test period extended over $168 \mathrm{~h}$, whereafter the final mud bed height was measured. From the supernatant clarity results presented in Fig. 2 it can be seen that at a high gypsum dosage the material has settled out significantly after a $24 \mathrm{~h}$ period. Although similar amounts of settling can be achieved with a lower gypsum dosage, it will take considerably longer to settle out. The higher the dosages of gypsum, the clearer the supernatant liquid that was recovered. A clarity reading of 0 NTU indicates an absolutely clear fluid. What was interesting to note was that after a period of time no further compaction of the sludge bed seemed to occur, although the super-fine material continued to settle, and the clarity of the supernatant fluid kept on improving with time. 


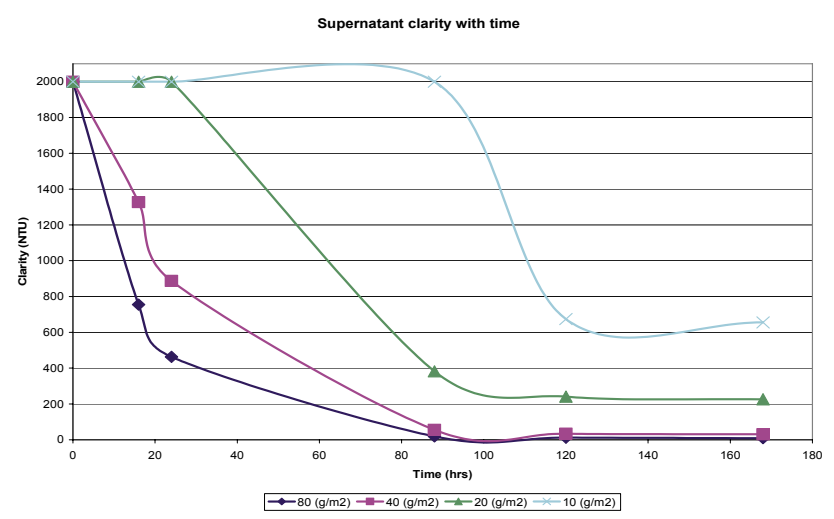

Figure 2

Supernatant clarities with time

\section{Comparison of slurry and dry dosing}

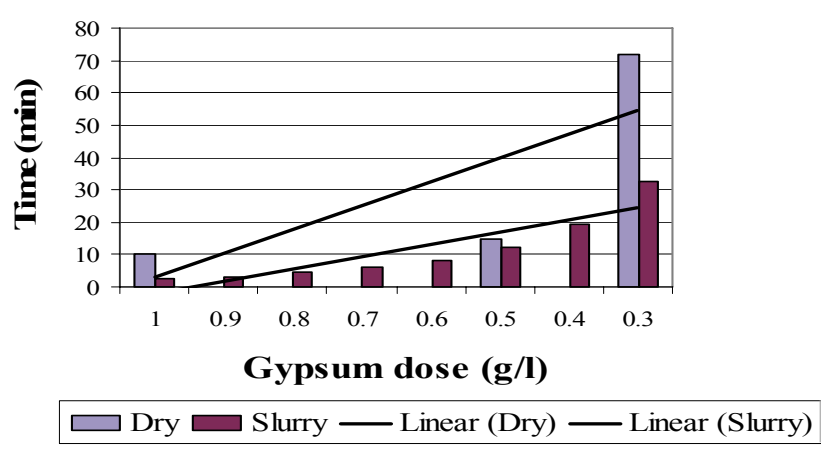

Figure 3

Comparison between slurry and dry dosing settling rates

Assuming that there will be enough gypsum in the solution, it can be concluded that once the stable colloidal particles have been destabilised, they will remain destabilised and settle out over a period of time.

\section{Slurry dosing}

Gypsum slurry was made up by adding the minimum amount of water to different amounts of gypsum to make up concentrations ranging from $0.3 \mathrm{~g} / \ell$ to $1 \mathrm{~g} / \ell$, increasing dosage strengths by increments of $0.1 \mathrm{~g} / \ell$. As with the dry dosing, it was found that at the higher slurry dosages faster settling times were achieved. The data depicted in Fig. 3 also indicated that faster settling rates were achieved by using the slurry dosing technique than when using dry powder. This can possibly be explained by taking into consideration the fact that the dry dosing technique did not allow sufficient inter-particle contact, thus allowing the gypsum to gravitate through the water. The slurry dosing samples were mixed vigorously, thus promoting maximum particle contact. Slurry dosing would also have promoted faster and more gypsum dissolution, which would have aided a greater degree of destabilisation and hence faster settling times.

The results from the multiple dosing test work were even more promising. A comparison was done between dry and slurry dosing. The sample was treated with an initial dosage of $1 \mathrm{~g} / \mathrm{l}$ and left to settle. After a period of time, half of the initial dosage $(0.5 \mathrm{~g} / \ell)$ was added again to the sample and it was allowed to settle. The test was repeated with dosage concentrations of $0.5 \mathrm{~g} / \ell$ initially, followed by another dosage of $0.25 \mathrm{~g} / \ell$. As the destabilised slimes interface

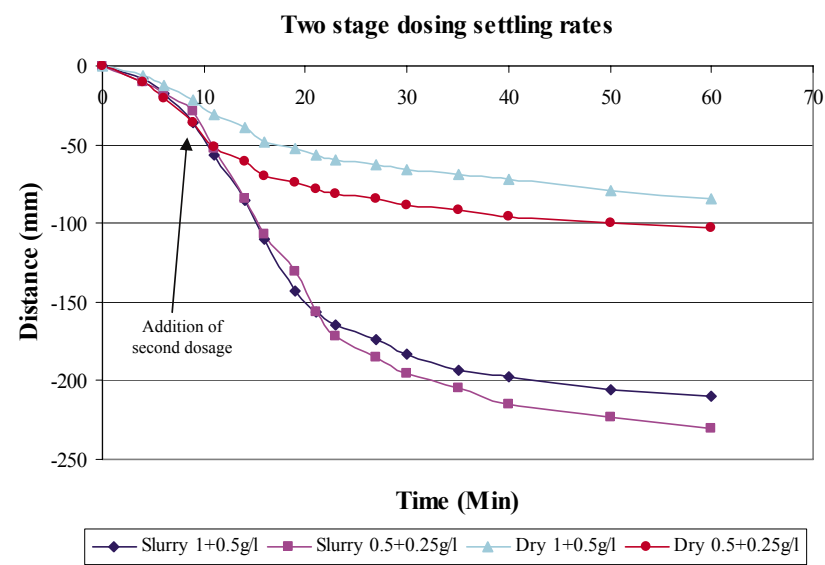

Figure 4

Two-stage dosing settling rates (compare with Fig. 5 where different 1:0.5 ratios where evaluated)

Two stage dosing settling rates Multiple dose concentrations

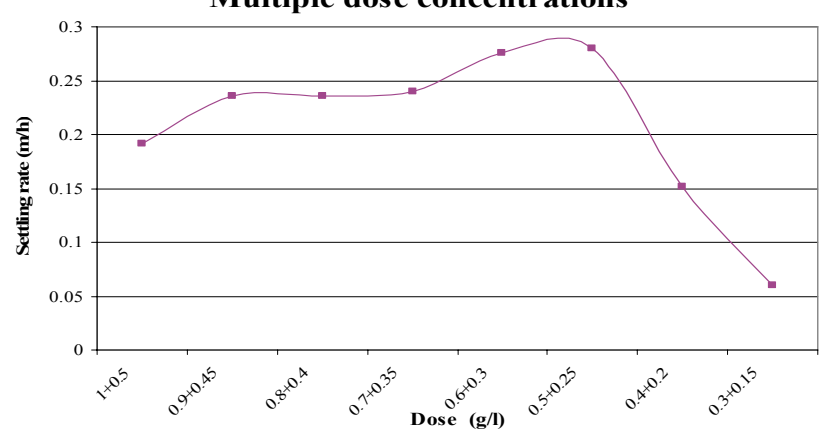

Figure 5

Two-stage dosing settling rates at multiple dosage concentrations

settled out over time, the distance were monitored and recorded. It also found that a two-stage dosing approach yielded better settling rates than single dosing, as indicated in Fig. 4. It was thus decided to extend the test work on the two-stage dosing technique.

The first dosage concentrations ranged from $0.3 \mathrm{~g} / \mathrm{l}$ to $1 \mathrm{~g} / \mathrm{l}$, and the second dosage concentrations were always half that of the first dosage. The samples were treated with the first dosage, mixed vigorously, left to settle for a period of time, and then treated with the second dosage before further settling were allowed to occur. The optimum settling rate occurred at a first/ second dosage concentration of about $0.6 \mathrm{~g} / \ell: 0.3 \mathrm{~g} / \ell$. No real added benefit was gained by dosing with higher concentrations; in fact, settling rates became worse at the higher dosages. It was observed that if the water was overdosed, "gelling" took place which inhibited the settling of the particles, even though the clay particles were destabilised. These results are graphically represented in Fig. 5.

\section{Compatibility with flocculants}

From visual observations, it was concluded that using gypsum exclusively would not give the desired settling rates needed in the thickening circuit due to the short residence time in the thickener. The compatibility of using gypsum as a coagulant in conjunction with commercial flocculants therefore needs to be established and investigated (Fuyane, 2001). 


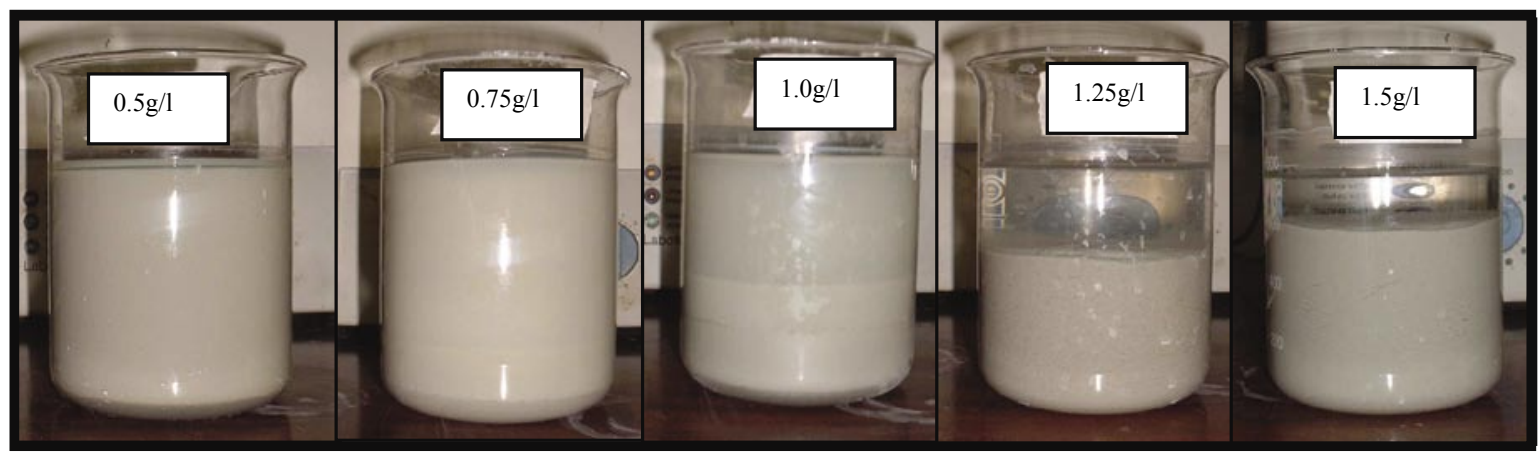

Figure 6

Appearance of slurry after the addition of different gypsum concentrations

\begin{tabular}{|l|c|c|l|}
\hline \multicolumn{4}{|c|}{ TABLE 4 } \\
\hline $\begin{array}{l}\text { Flocculant } \\
\text { used }\end{array}$ & $\begin{array}{c}\text { Con- } \\
\text { sump- } \\
\text { tion } \\
\text { (g/ton) }\end{array}$ & $\begin{array}{c}\text { Tur- } \\
\text { bidity } \\
\text { (NTU) }\end{array}$ & Observations \\
\hline Nalco 9808 & 346 & 720 & $\begin{array}{l}\text { Slurry appeared overdosed } \\
\text { Turbid supernatant }\end{array}$ \\
\hline $\begin{array}{l}\text { Magnafloc } \\
\text { E10 }\end{array}$ & 1370 & 35 & Clear supernatant \\
\hline $\begin{array}{l}\text { AD10 } \\
\text { Magnafloc } \\
\text { 156 }\end{array}$ & 350 & 935 & $\begin{array}{l}\text { Slurry appeared overdosed } \\
\text { Turbid supernatant }\end{array}$ \\
\hline AD2 & 1385 & 32 & Clear supernatant \\
\hline
\end{tabular}

\section{Determination of the required gypsum dosage}

It was observed that the optimum coagulation took place between $1 \mathrm{~g} / \ell$ and $1.25 \mathrm{~g} / \ell$ gypsum. Although the sample dosed with the $1.25 \mathrm{~g} / \ell$ concentration had a clear supernatant, the sample dosed with the $1 \mathrm{~g} / \mathrm{l}$ concentration formed pin flocs, which is advantageous for effective flocculation. The sample dosed with $1.5 \mathrm{~g} / \ell$ gypsum showed signs of overdosing. Larger floc structures were created that inhibited particles settling effectively into a compact bed. At dosages lower than $1 \mathrm{~g} / \ell$, very few pin flocs were formed and very little settling took place, hence the supernatant fluid stayed turbid. All of the subsequent tests were conducted at a gypsum concentration of $1.25 \mathrm{~g} / \ell$. These results are depicted in Fig. 6.

\section{Determination of the most suitable flocculant}

The flocculant currently used on the mine, a commercial product called Nalco 9808 (Ondeo Nalco), proved not to be effective in flocculating the gypsum treated suspension. Only a small fraction of the clays were flocculated at a relatively low dosage. However, with the addition of more flocculant, the supernatant fluid remained turbid and the solids began to appear over-flocculated. The same phenomenon was observed when using other commercial flocculants, Magnafloc 156 (Pelichem) and AD10 (Floerger).

The two flocculants that did perform satisfactory were Magnafloc E10 (Pelichem) and AD2 (Floerger). Both of these flocculants have a very low anionic charge content (between 1 to $5 \mathrm{wt} \%$ ). However, the flocculant consumption required to obtain clear overflows was exorbitantly high at $1385 \mathrm{~g} / \mathrm{ton}$, as compared to the current overall plant consumption of $6 \mathrm{~g} / \mathrm{t}$. It must be said however, that the thickening circuit currently does not operate very efficiently due to the clay problems experienced. The results of this part of the investigation are summarised in Table 4.

\section{Determination of the most appropriate dosing method}

The critical coagulation concentration was determined to be $1.25 \mathrm{~g} / \ell$ of gypsum. It was also previously established that a two-stage dosing technique is more effective than a single stage dosing technique. The overall gypsum dosage of $1.25 \mathrm{~g} / \ell_{\text {was }}$ thus split into different ratios between the first and the second dosing stages. The three ratios tested were 25:75, 50:50 and 75:25 respectively, between the first and second dosage. A lower first dosage resulted in higher settling rates compared to a higher level first dosage. This is attributed to the lower dosage enabling pin flocs to form, whereas the larger second dosage then acted as the flocculant which aided the settling process. There was in fact very little difference between the settling rates of the 25:75 and 50:50 ratios. At the 75:25 ratio, the opposite was observed. When the higher first dosage ratio was used, gelling took place and this inhibited settling, resulting in the turbid supernatant overflow. The turbidity of the supernatant increased as the ratio of the first to the second dosage increased. The results are graphically shown in Figs. 7 and 8.

The flocculant consumptions for the three different dosing ratios showed that at the lower gypsum dosing ratio, the overall flocculant consumption was also the lowest. This is attributed to the better coagulation that took place during the first dosing stage. When the second dosage of gypsum was added, it aided the flocculation process and therefore less flocculant was needed.

The lowest overall flocculant consumption recorded was just above $1000 \mathrm{~g} / \mathrm{t}$ (obtained at a dosing ratio of 25:75) and was an improvement on the previously reported consumption of 1385 $\mathrm{g} / \mathrm{t}$. The overall flocculant consumption generally increased as the ratio of the first to second dosage increased. The results obtained with these tests are shown in Fig. 9.

\section{Plant-scale test work}

The results depicted in Fig. 10 indicate that the turbidity measurements on the samples of the water in the thickener showed that the clarity of the water improved over time, even when taken at different depths. After the application of the second gypsum dosage, a marked increase in the clarity was observed. After the $15 \mathrm{~d}$ period, the clarity of the water at a depth of $1.5 \mathrm{~m}$ was almost the same as that of the water at the surface. 


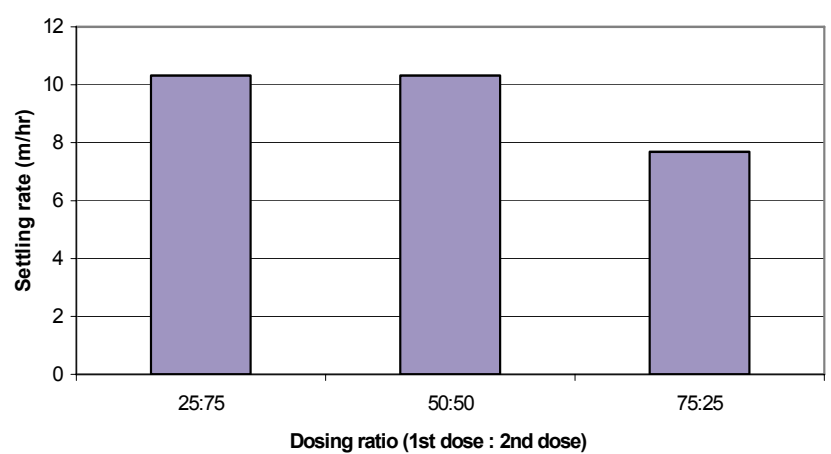

Figure 7

Settling rate of samples treated with different gypsum dosing ratios together with a flocculant aid

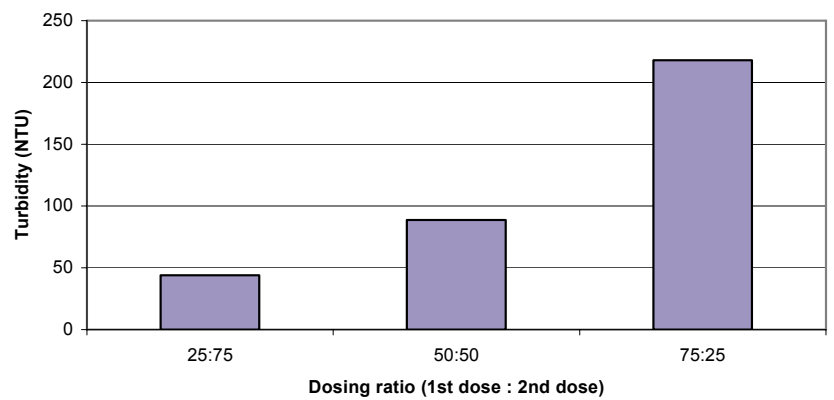

Figure 8

Turbidity of samples treated with different gypsum dosing ratios (test conditions given in experimental section)

Although the rate of clarification was significantly slower when compared to settling rates typically achieved in a thickening circuit, the treatment of the slimes dam is not that dependant upon fast settling times, since the residence time in the slimes dam is extremely long. It was interesting to note that after the second day of the first gypsum addition, a fervent growth of algae occurred in the thickener. This might have been due to the phosphates and some other impurities present in the gypsum, since it originated from a fertiliser manufacturing process. It is possible that this may have increased the nutrients in the water, and together with the fact that sunlight could also now penetrate the clarified water, it resulted in the algal growth. The algae

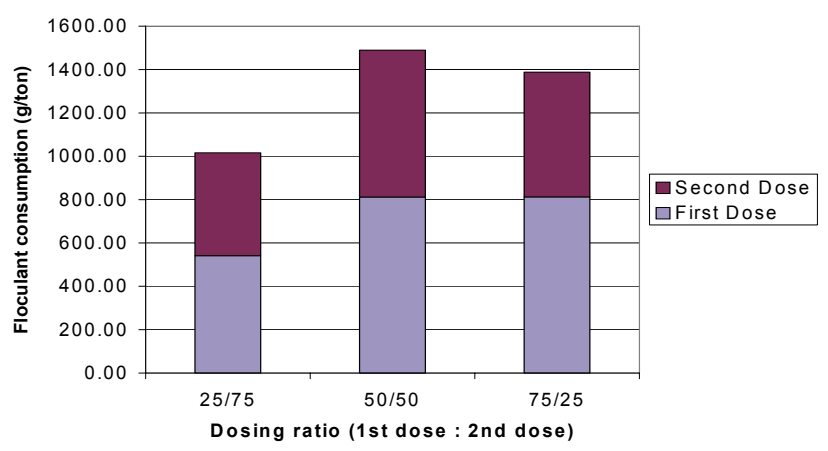

Figure 9

Flocculant consumption of samples treated with different gypsum dosing ratios

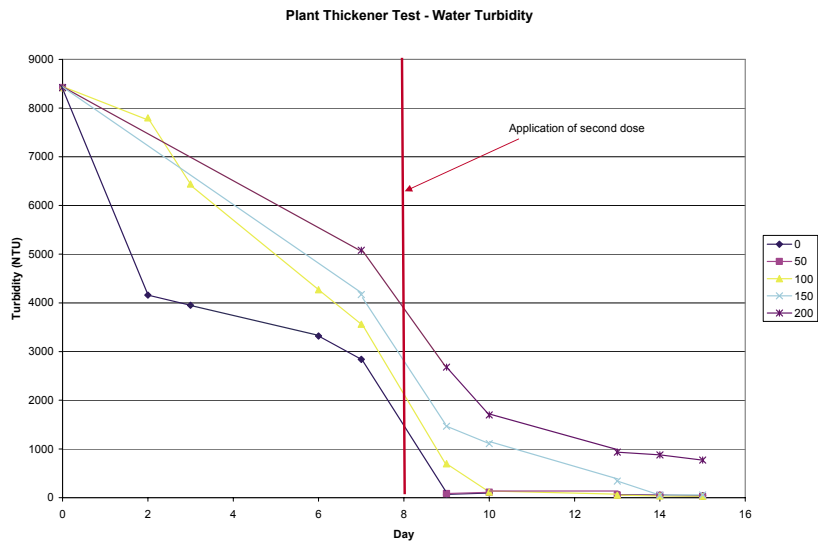

Figure 10

Thickener clarities over a period of time (for test conditions see experimental section)

died within a day or two, presumably after all the nutrients in the water had been consumed.

Figure 11 illustrates the improvement in the water quality very clearly. In Photo $\mathbf{A}$ the thickener is filled with untreated slimes dam water, whilst in Photo B, clean water can be seen after the $15 \mathrm{~d}$ period. Although the test was ended after $15 \mathrm{~d}$, the water clarity continued to improve until the thickener was drained after about 4 weeks. The water at a depth of $2 \mathrm{~m}$ had a clarity of about 150 NTU.

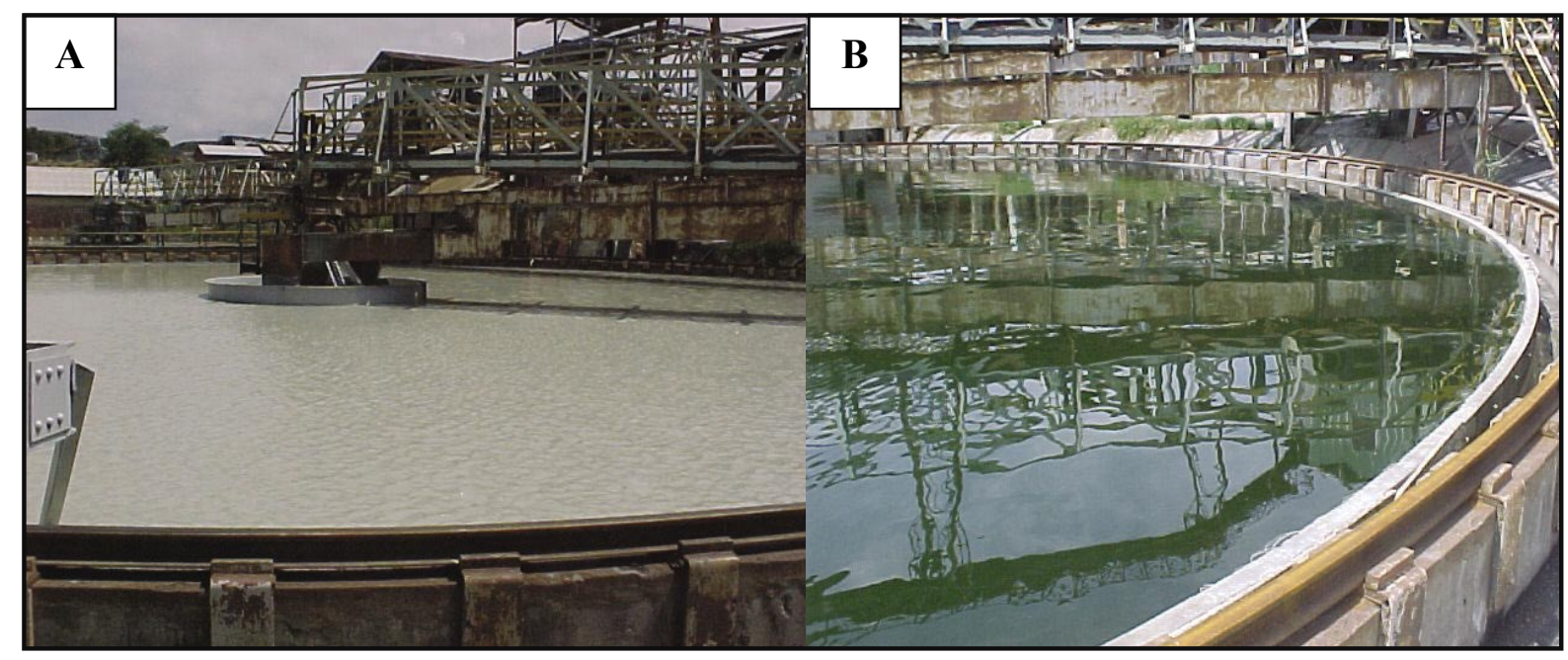

Figure 11

Comparison of original untreated slimes dam water and gypsum treated water 


\begin{tabular}{|c|c|c|c|c|}
\hline \multicolumn{5}{|c|}{ TABLE 5 } \\
\hline $\begin{array}{c}\text { Eypsum } \\
\text { concentration } \\
(\%)\end{array}$ & $\mathbf{p H}$ & $\begin{array}{c}\text { Oxygen } \\
\text { concentration } \\
\text { (mg//) }\end{array}$ & $\begin{array}{c}\text { Daphnia lethality } \\
\text { after 48 h } \\
(\%)\end{array}$ & $\begin{array}{c}\text { Algae growth (+) } \\
\text { or inhibition (-) } \\
(\%)\end{array}$ \\
\hline 1.56 & 7.6 & 8.0 & 0 & $=$ \\
\hline 3.13 & 7.2 & 7.2 & 0 & +97 \\
\hline 6.25 & 7.0 & 7.1 & 0 & +106 \\
\hline 12.5 & 6.9 & 7.2 & 0 & +115 \\
\hline 25.0 & 6.8 & 7.4 & 0 & +110 \\
\hline 50.0 & 6.7 & 7.3 & 0 & +111 \\
\hline 100 & 6.0 & 7.7 & 0 & +49 \\
\hline
\end{tabular}

\begin{tabular}{|c|c|c|c|c|}
\hline \multicolumn{5}{|c|}{$\begin{array}{c}\text { TABLE } 6 \\
\text { Radiological results }\end{array}$} \\
\hline $\begin{array}{l}\text { Sample } \\
\text { Top row value } \\
\text { Bottom row value }\end{array}$ & Method & $\begin{array}{l}\text { Uranium } \\
(\mathrm{mg} / \mathrm{l}) \\
(\mathrm{Bq} / \mathrm{g})\end{array}$ & $\begin{array}{l}\text { Thorium } \\
\text { (mg/l) } \\
(\mathrm{Bq} / \mathrm{g})\end{array}$ & $\begin{array}{l}\text { Potassium } \\
(\% \mathrm{~m} / \mathrm{m}) \\
(\mathrm{Bq} / \mathrm{g})\end{array}$ \\
\hline \multirow[t]{2}{*}{$\begin{array}{l}\text { Supplier: } \\
\text { Main dump }\end{array}$} & Gamma spectrometry & $\begin{array}{c}3.715 \pm 0.079 \\
46.07 \pm 0.98\end{array}$ & $\begin{array}{c}15.501 \pm 0.251 \\
62.93 \pm 1.02\end{array}$ & $\begin{array}{c}0.073 \pm 0.004 \\
23.14 \pm 1.27\end{array}$ \\
\hline & \begin{tabular}{|l} 
Thick source \\
alpha counting \\
\end{tabular} & $\begin{array}{c}4.43 \pm 0.19 \\
54.93 \pm 2.36\end{array}$ & $\begin{array}{c}9.27 \pm 0.64 \\
37.64 \pm 2.60 \\
\end{array}$ & $? ?$ \\
\hline $\begin{array}{l}\text { Supplier 2: } \\
\text { Railway storage E }\end{array}$ & Gamma spectrometry & $\begin{array}{c}3.698 \pm 0.078 \\
45.86 \pm 0.97\end{array}$ & $\begin{array}{c}15.974 \pm 0.255 \\
64.85 \pm 0.98\end{array}$ & $\begin{array}{c}0.033 \pm 0.003 \\
10.46 \pm 0.95\end{array}$ \\
\hline \multirow[t]{2}{*}{$\begin{array}{l}\text { Supplier 3: } \\
\text { Railway storage W }\end{array}$} & Gamma spectrometry & $\begin{array}{c}4.395 \pm 0.091 \\
54.50 \pm 1.13\end{array}$ & $\begin{array}{c}12.671 \pm 0.242 \\
54.44 \pm 0.98\end{array}$ & $\begin{array}{c}0.122 \pm 0.004 \\
38.67 \pm 1.27\end{array}$ \\
\hline & $\begin{array}{l}\text { Thick source } \\
\text { alpha counting }\end{array}$ & $\begin{array}{c}3.87 \pm 0.18 \\
47.99 \pm 2.23\end{array}$ & $\begin{array}{c}27.40 \pm 0.64 \\
101.24 \pm 2.60\end{array}$ & \\
\hline
\end{tabular}

- Radioactivity 0.2 - $100 \mathrm{~Bq} / \mathrm{g}$ : National Nuclear Regulator (NNR) to use its discretion in regulating substance

- $\quad$ Radioactivity $>100 \mathrm{~Bq} / \mathrm{g}:$ A nuclear license will be required

\section{Environmental test work}

An initial screening test with un-clarified slimes dam water showed that it was not toxic to Daphnia ( $0 \%$ lethality) and that significant algal stimulation and growth $(138 \%)$ was observed, possibly because of the presence of nutrients in the phosphogypsum. The results of the different tests on the gypsum-treated dam water are presented in Table 4 . The test concentrations ranged from a 1.56 to a $100 \%$ gypsum solution in the Daphnia test and from a 3.13 to a $100 \%$ gypsum solution in the algae test. None of the test concentrations exhibited any lethal activity, indicating an absence of toxicity (Claassen, 2003). Algal growth was stimulated by all the test concentrations. In general, the $\mathrm{pH}$ and oxygen concentrations of the test samples were within the limits required for sustaining of aquatic life (South Africa, Department of Water Affairs and Forestry (DWAF), 1996). The results are summarised in Table 5.

\section{Radio-activity measurements}

The results of the radiological analyses are given in Table 6 . Both the full parent equivalent activity $(\mathrm{mg} / \ell)$ and the radiation activity $(\mathrm{Bq} / \mathrm{g})$ are reported. Only one of the samples showed activity at the limit of $100 \mathrm{~Bq} / \mathrm{g}$ set by the NNR. Although there is some variability between the different samples and the different measurement methods employed, the radioactivity level of the gypsum appeared to be at a sufficient level for the granting of a permit to allow its handling and transportation.

\section{Conclusions}

The following conclusions were made from this investigation:

- Phosphogypsum can successfully destabilise a kimberlitic ore clay suspension and enhance the flocculation and clarification process.

- Adding the gypsum as a dry powder resulted in poor settling rates. However, when sufficient residence time was allowed, acceptable clarities were obtained.

- The settling rates of the colloidal suspensions containing kimberlite improved when the gypsum was added as a slurry, probably as a result of improved dissolution and inter-particle contact.

- When the gypsum was added in a two-stage manner, it resulted in improved supernatant clarities compared to those achieved with a single dosage addition. A two-stage slurry addition is thus the preferred methodology to be followed.

- The addition of flocculants to aid in the settling rates, improved it. However, high flocculant consumptions were experienced which increased the operational cost.

- The residence time needed for efficient settling will depend on where the gypsum will be added to the process, and will influence the decision of whether flocculants will be needed or not.

- Plant-scale test work confirmed the proposed dosing methodology. Positive results were obtained, despite the growth of algae after the second day. The algae died later on, leaving a slight greenish tint to the water, without affecting the turbidity measurements, and the 
clarity of the water continued to improve over a period of time.

- Toxicity tests indicated that gypsum should not have any detrimental effects on an ecosystem, based on the fact that no lethality was revealed with the Daphnia organisms. In fact, a positive growth was experienced during the algae test, which indicated the presence of nutrients. These tests were conducted as an additional safety precaution in case some of the slimes dam water accidentally flowed out despite the intention to recycle the process water and not discharge it to the environment.

- The radioactivity level of the gypsum appears to be low enough to allow routine handling and transportation thereof.

- It can be concluded that gypsum can be used safely and successfully to increase the flocculation of the slimes dam's water to enable the recycling thereof, which would inevitably help to save potable water consumption and increase the operational lifespan of the slimes dam.

\section{Acknowledgments}

The authors wish to express their gratitude to the management of Premier Mine, De Beers Consolidated Mines Limited, for permission to conduct this investigation and their financial assistance. Thanks are also due to the De Beers Technical Services Division and the CSIR (Water, Environment and Forestry Technology Division) who assisted in the laboratory test work and toxicity analysis.

\section{References}

CLAASSEN M (2003) Ecological and Hygiene Impact Assessment: No. 7 Slimes Dam Water Clarification Project. CSIR, Water, Environment and Forestry Technology. Project No. PM608/2003.

COTEA I, ROMANESCU A and DUMITRESCU C (1986) Researches concerning the harmful components elimination from phosphogypsum for using it as a cement setting time regulator. Proc. $8^{\text {th }}$ Int. Chem. Cement Congress (ICCC). Rio de Janeiro, Brazil,. Vol. VI 430-433.

CUTTING NG and LLOYD T (1996) Probabilistic Dam Break Flood Analysis. Anglo American Corporation. Civil Engineering Department. Report No. CED/103/96.

DEPARTMENT OF WATER AFFAIRS AND FORESTRY (DWAF) (1996) South African Water Quality Guidelines ( $2^{\text {nd }}$ edn.) Vol. 1-8.

ERDOGAN Y, DEMIRBAS A and GENC H (1994) Partly refined chemical by-product gypsums as cement additives. Cem. \& Concr. Res. 24 (4) 601-604.

FUYANE Z (2001) Treatment of Premier ROM Slurry with Gypsum and Flocculant. De Beers Technical Services Division. Company report.
GOVERNMENT GAZETTE (1994) Number 15670 - Regulation R849 GREEN C (2000) A Mathematical Model to Determine Slimes Dam Life. B.Tech. Project Report, Technikon Pretoria.

LANGEFELD GM (2001a) Novel Applications of a Gypsum Coagulant for Problematic Kimberlites. De Beers Technical Services Division. Company report.

LANGEFELD GM (2001b) The Application of a Gypsum Coagulant to Recover Clear Water from Premier Mine No. 7 Dam. De Beers Technical Services Division. Report No. 2001-06-05.

MURAKAMI K (1968) By-product gypsum from various chemical industries, as a retarder for the setting of cement. Proc. $5^{\text {th }}$ Int. Chem. Cement Congress (ICCC). Tokyo, Japan.Vol. IV. 457-510.

OLMEZ H and YILMAZ VT (1988) Infrared study on the refinement of phosphogypsum for cements. Cem. \& Concr. Res. 18 (3) 449-454.

OLMEZ H and ERDEM E (1989) The effects of phosphogypsum on the setting and mechanical properties of Portland cement and trass cement. Cem. \& Concr. Res. 19 (3) 377-384.

POTGIETER JH and HOWELL-POTGIETER SS (2001) A plant investigation into the use of treated phosphogypsum as a set-retarder in OPC and an OPC/fly ash blend. Min. Eng. 14 (7) 791-795.

POTGIETER JH, POTGIETER SS and McCRINDLE RI (2004) A comparison of the performance of various synthetic gypsums in plant trials during the manufacturing of OPC clinker. Cem. \& Concr. Res. 34 (12) 2245-2250

SINGH M, RESHI SS and TANEJA CA (1984) Rendering phosphogypsum suitable for plaster manufacture. Indian J. Technol. 22 22-28.

SINGH M, GARG M and RESHI SS (1993) Purifying phosphogypsum for cement manufacture. Constr. \& Build. Mater. 7 (1) 3-7.

SLABBERT JL, OOSTHUIZEN J, VENTER EA, HILL E, DU PREEZ $\mathrm{M}$ and PRETORIUS PJ (1998) Development of Guidelines for Toxicity Bio-Assaying of Drinking and Environmental Waters in South Africa. WRC Report No. 358/1/98. Water Research Commission, Pretoria, South Africa.

TABIKH AA and MILLER FM (1976) The nature of phosphogypsum impurities and their influence on cement hydration. Cem. \& Concr. Res. 1 (6) 663-678.

US EPA (1978) The Selenastrum capricornutum Printz Algae Assay Bottle Test: Experimental Design, Application and Data Interpretation Protocol. Environmental Protection Agency, Corvallis, Oregon. Report No. EPA 600/9-78/018.

US EPA (1985) Methods for Measuring the Acute Toxicity of Effluents to Freshwater and Marine Organisms. Environmental Protection Agency, Cincinnati, Ohio. Environmental Monitoring and Support Laboratory. Report No. EPA/600/4-85/013.

US EPA (1991) Methods for Measuring the Acute Toxicity of Effluents to Aquatic Organisms ( $4^{\text {th }}$ edn.) Environmental Protection Agency, Cincinnati, Ohio. Environmental Monitoring and Support Laboratory. Report no. EPA/600/4-90-027.

VIETTI AJ (1991) The Kimberlitic Clay Stability Problem at Premier Mine: A Case Study. De Beers Diamond Research Laboratory. Mineral Processing Division. Report No. E66/005/003.

VIETTI AJ, LANGEFELD GM, RAMULAI S and DUNN F (1999) Slimes Characterisation and Flocculation Test Procedure. De Beers Technical Services Division. Report No. 1999-07-08. 